\title{
Miranda
}

Revue pluridisciplinaire du monde anglophone /

Multidisciplinary peer-reviewed journal on the English-

speaking world

$22 \mid 2021$

Unheard Possibilities: Reappraising Classical Film

Music Scoring and Analysis

\section{Pádraig Ó Méalóid, Poisoned Chalice. The Extremely Long and Incredibly Complex Story of Marvelman (and Miracleman) and Mud and Starlight. The Alan Moore Interviews, 2008-2016}

\section{Cyril Camus}

\section{(2) OpenEdition}

Electronic version

URL: http://journals.openedition.org/miranda/38271

DOI: $10.4000 /$ miranda.38271

ISSN: 2108-6559

\section{Publisher}

Université Toulouse - Jean Jaurès

Electronic reference

Cyril Camus, "Pádraig Ó Méalóid, Poisoned Chalice. The Extremely Long and Incredibly Complex Story of Marvelman (and Miracleman) and Mud and Starlight. The Alan Moore Interviews, 2008-2016", Miranda [Online], 22 | 2021, Online since 17 March 2021, connection on 27 April 2021. URL: http:// journals.openedition.org/miranda/38271 ; DOI: https://doi.org/10.4000/miranda.38271

This text was automatically generated on 27 April 2021.

\section{(i) 8

Miranda is licensed under a Creative Commons Attribution-NonCommercial-NoDerivatives 4.0 International License. 
Pádraig Ó Méalóid, Poisoned Chalice. The Extremely Long and Incredibly Complex Story of Marvelman (and Miracleman) and Mud and Starlight. The Alan Moore Interviews, 2008-2016 Cyril Camus

\section{REFERENCES}

Pádraig Ó Méalóid, Poisoned Chalice. The Extremely Long and Incredibly Complex Story of Marvelman (and Miracleman). (Dublin: Poisoned Chalice Press, 2018) 317 p, ISBN : 978-1916493902.

Pádraig Ó Méalóid, Mud and Starlight. The Alan Moore Interviews, 2008-2016. (Dublin: Poisoned Chalice Press, 2019) 364 p, ISBN : 978-1916493919. 

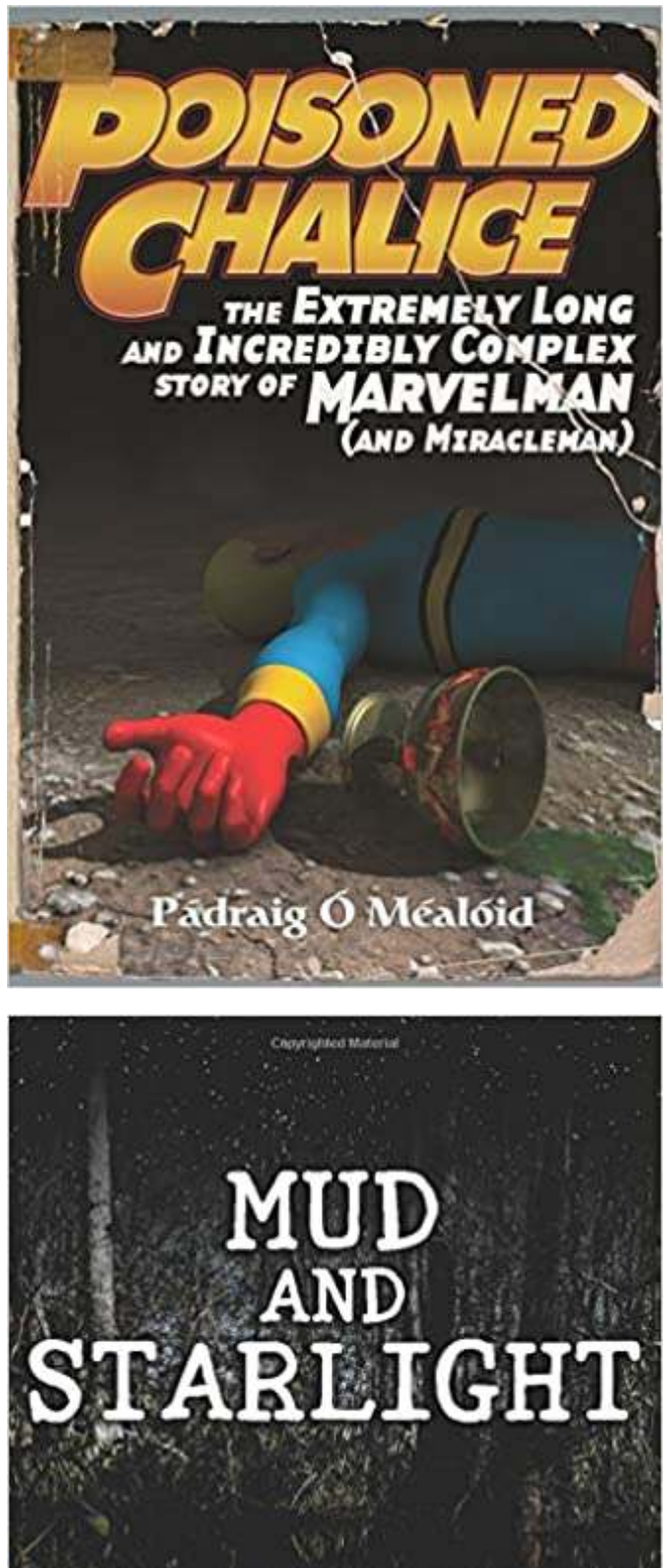

\section{THE ALAN MOORE INTERVIEKS $2008-2016$}

\section{Pádraig Ó Méalóid}

Pádraig Ó Méalóid is a former Irish bookseller, and an independent scholar. His interviews of comics writers and artists, his writings on Flann O'Brien, book censorship in Ireland, British comics and fantasy, and especially on Alan Moore's works, have appeared on numerous Internet outlets. $\mathrm{He}$ is also known for some academic publications such as his contribution to Joseph M. Sommers's Conversations with Neil Gaiman, published by University Press of Mississippi in 2018. He has been a prominent 
figure in international comics fandom and contributor to events and publications in this field for many years.

2 Serialized in 2013 on the comics-related news website The Beat, then updated and selfpublished in 2018 through ó Méalóid's ad hoc company Poisoned Chalice Press, his first book, Poisoned Chalice. The Extremely Long and Incredibly Complex Story of Marvelman (and Miracleman), comes as close as it gets to being a Holy Grail, so to speak, for anybody interested in the numerous legal entanglements that have led to a twenty-one-year hiatus between the bankruptcy of US publisher Eclipse Comics in 1993 and the reprint of most of its legendary superhero series Miracleman from 2014 onwards. As noted in the subtitle of the book, there is a unique complexity to the history of litigation behind this hiatus, and a significant part of it derives from ambiguities regarding copyright ownership, dating back to decades before Eclipse even started to publish this comics series. Indeed, the protagonist of the series, originally called Marvelman, was created in 1950s Britain, by comics writer and artist Mick Anglo, for the company L. Miller and Son, Ltd., and this typically upbeat and naive character from 1950s children's fantasy comics was recreated in the early 1980s, in a significantly darker and more serious mode, by comics writer Alan Moore (of Watchmen, From Hell and The League of Extraordinary Gentlemen fame)-along with artists Garry Leach and Alan Davis-for a British comics magazine named Warrior, published by the company Quality Communications and edited by its founder Dez Skinn. In the mid-1980s, it was retitled Miracleman to appease the giant US comics corporation Marvel, and passed on to Eclipse, which reprinted it in America, then published more installments of Alan Moore-written stories with new artists, then a new story arc penned by Neil Gaiman (of Sandman, American Gods and Good Omens fame) and illustrated by Mark Buckingham; then Eclipse published the first two issues of another story arc by Gaiman and Buckingham, but it eventually went bankrupt, leaving Gaiman and Buckingham's new story unfinished.

3 As Ó Méalóid's book shows, the character was doomed to become a legal nightmare from its very creation in the 1950s, as it was already meant to be a British plagiarization of US company Fawcett's character Captain Marvel, which had, itself, been sued as a plagiarization of Superman by the latter's own publisher, DC Comics (then called National Periodical Publications). Besides, at every acquisition of the character by a new company (by Quality from L. Miller and Son, and by Eclipse from Quality), the exact degree of ownership of the companies, writers and artists involved over the character, his name, his visual design, or the right to print new adventures with Marvelman-related characters, was never fully and satisfactorily settled, a situation which became even more complicated when the shaky rights were acquired by Eclipse, because copyright laws in Britain and America are very different. So, when Eclipse went bankrupt, and auctioned off its still-shaky rights to Image Comics owner Todd McFarlane as he was, himself, involved in a litigation with Miracleman writer Neil Gaiman over the rights to other, completely unrelated comics characters, all the accumulated legal problems came to Kafkaesque, insoluble fruition. As Poisoned Chalice ascertains, the story is far from ending there, but this summary does at any rate.

4 Ó Méalóid's study is an inquiry into the difficult matter of who owns what, regarding the character's two incarnations and the stories about him. The work carried out by Poisoned Chalice's author is almost that of a detective, or an investigative reporter. Besides relying on interviews of the parties involved, conducted either by himself or by 
previous Miracleman exegetes such as George Khoury (who wrote TwoMorrows Publishing's 2001 Eisner-nominated Kimota! The Miracleman Companion)-and on the careful examination of indicia pages in long-out-of-print comic books that are available to him thanks to his impressive achievements as a collector-Ó Méalóid also went through page after page of records from US courts, the UK Registrar of Companies or the US Patent and Trademark Office, and cease-and-desist letters. Thanks to this array of sources, he delivers an unprecedentedly detailed history and reconstruction of the whole case, all while offering, at the same time, a very lively depiction of the creative and commercial life of the comics industry, from 1950s Britain to 2010s America. He also sometimes corrects the record regarding some dubious statements made by other authors, memorably calling Gerard Jones's 2004 Eisner-winning book Men of Tomorrow: Geeks, Gangsters and the Birth of the Comic Book "an example of someone not letting the lack of facts get in the way of a good story."

5 As a non-academic endeavour, Poisoned Chalice lacks some usual convenient features, such as an index, or complete bibliographical references for every document quoted or cited, but there are regular footnotes and the documents are always clearly identified, and although the page setting of the book is sometimes confusing (with some footnotes appearing on the wrong page), the seriousness of the content certainly speaks for its value. Does Pádraig Ó Méalóid find out who actually owns Miracleman? No-but would The Trial be as great if Joseph $\mathrm{K}$. found out why he was arrested?

The year after publishing Poisoned Chalice, Ó Méalóid released a collection of interviews entitled Mud and Starlight. The Alan Moore Interviews, 2008-2016. Most of those interviews were carried out by phone, and initially published either on the blog of British bookstore chain Forbidden Planet International, or on The Beat. Four were made by email, one of which was initially published on one of Ó Méalóid's own websites (slovobooks.wordpress.com), while another appeared in Irish print literary journal gorse, and two were previously unpublished. Those interviews obviously offer insights into the history of the creation and reboot of Marvelman/Miracleman, and into the legal trouble they led to. Actually, one of the interviews is mostly about that and is often quoted from in Poisoned Chalice. As for the rest, there are numerous insights into Moore's works and their development over the years, from the nineteen-year creative process behind Moore and artist Kevin O'Neill's giant crossover comics series The League of Extraordinary Gentlemen (1999-2018), to the ten-year writing of Moore's sprawling second novel Jerusalem (2016). The interviews also frequently provide reflections over Moore's musical work, be it in the form of rock and pop songs with various collaborators or, more pointedly, his multimedia theatrical performances accompanied by the music of Tim Perkins or Gary Lloyd. His forays into filmmaking are also documented, from his and Mitch Jenkins's Jimmy's End series of short movies (2014-2016) to their feature-length sequel The Show, whose March 2020 official release at South by Southwest has been postponed as the US festival was cancelled due to the COVID-19 pandemic. These dialogues also show successive stages of Moore's everdegrading relationship with the comics industry, as well as his friendship and collaborations and/or cross-fertilization with fellow British writers Steve Moore and Iain Sinclair. Moore can be seen teasing some aspects of the last League of Extraordinary Gentlemen volume, The Tempest (2018), seven years before its publication-as he is writing the second volume of a spin-off trilogy of this series. As for Ó Méalóid, his extensive knowledge and understanding of Moore's work lead him to guess, three years in advance, that the last part (2012) of Century (2009-2012), the third volume of The 
League, would star Harry Potter. Likewise, he guessed five years in advance that The Tempest would show the Nautilus transformed into a spaceship. Finally, if you are not sure about what those rumours you heard mean, about Alan Moore having performed some stand-up comedy in the early 2010s, there are thorough explanations about that in one interview. Generally speaking, Ó Méalóid's two books can be safely characterized as treasure troves of reference to look up for anybody researching Moore's works and career, as well as, more generally, comics and fantasy fiction history, and the great sense of humour of both ó Méalóid and Moore himself (in the interviews) also make them a thoroughly enjoyable read.

\section{INDEX}

Keywords: British comics, comics industry, superheroes, litigation, copyright, fantasy fiction, interviews

Mots-clés: bande dessinée britannique, industrie de la bande dessinée, super-héros, litiges, droits d'auteur et de reproduction, fiction fantastique, entretiens

\section{AUTHORS}

\section{CYRIL CAMUS}

Professeur agrégé en $\mathrm{CPGE}$

Lycée Ozenne

cyril.camus@hotmail.fr 